\title{
Evaluation of antiviral activity of honeybee venom on DNA and RNA virus models
}

\author{
Rawhia H. Ramadan ${ }^{1}$; Aly F. Mohamed ${ }^{2}$ and Mohamed S. Abd El- Daim ${ }^{2}$ \\ 1-Faculty of Science, Benha University \\ 2-Virology Sector, VACSERA - Egypt
}

\section{ABSTRACT}

The virucidal activity (direct action) of bee venom on Herpes simplex virus type-1(HSV-1) and Adenovirus type -7(adeno-7) as a DNA virus models studies revealed that there was no significant decrease in HSV-1 infectivity titer after 3, 6 and 24 hours of treatments $(\mathrm{P}>0.05)$ while 48 hours later a significant viral depletion rate was recoded in the order of $1 \log (10) / 0.1 \mathrm{ml}$ was detected. Also, the virucidal activity on Adeno-7 virus model showed no change after insignificance 3 hrs of bee venom treatment. There was a significant depletion rate of virus infectivity titer 6 and 24 hrs post treatment recording $3.7 \log (10) / 0.1 \mathrm{ml}$ and $2.75 \log (10) / 0.1 \mathrm{ml}$ respectively. Also, the evaluation of virucidal activity of bee venom against RNA model virus of West Nile virus (WNV) revealed that there was a significant decreased in WNV infectivity titer post thermal treatment incubation at $37^{\circ} \mathrm{C}$ for 3,6 , and 24 and 48 hours post treatment with venom recording $5.1 \log (10) / 0.1 \mathrm{ml}, 4.5 \log (10) / 0.1 \mathrm{ml}$, $2.1 \log (10) / 0.1 \mathrm{ml}$ and $0.55 \log (10) / 0.1 \mathrm{ml}$ respectively. The antiviral activity of bee venom of HSV-1 as a DNA model virus showed that there was a non significant decrease in the infectivity titer post thermal treatment. In the mean time, the antiviral activity of bee venom against Adeno virus sero-type -7 revealed that there was a non significant decrease in Adeno-7 titer 3, 6 and 24 hours post incubation at $37^{\circ} \mathrm{C}$. Also, evaluation of the antiviral activity of bee venom against RNA model virus West Nile Virus revealed that there was a non significant decrease in West Nile Virus titer after incubation period of 3, 6 and 24 hours post treatment at $37^{\circ} \mathrm{C}$.

Antiviral activity of bee venom was also compared with that of the standard antiviral drug; interferon $\propto-2$ a (IFN - $\boldsymbol{c}$ 2a). HSV-1 was insignificantly decreased recording $5.5 \log (10) / 0.1 \mathrm{ml}$ in the bee venom treated cells compared to significant decrease when treated with (IFN - $\propto$ 2a) recording $3.2 \log (10) / 0.1 \mathrm{ml}$. In the mean time antiviral activity against adenovirus-7 recorded a significant decrease in virus infectivity titer recording $3.4 \log (10) / 0.1 \mathrm{ml}$ post bee venom compared with $3.25 \mathrm{log}$ (10)/0.1 ml post IFN treatment which mean that the in vitro studies of the effect of standard IFN used was the same as bee venom on the Adeno-7 virus. The RNA model virus ;WNV was well influenced by bee venom than IFN where the virus infectivity titer recorded $1 \log (10) / 0.1 \mathrm{ml}$ post bee venom treatment compared with $2.5 \mathrm{log}$ (10)/0.1 ml virus infectivity titer post IFN treatment.

Key Words: Honey bee venom, DNA and RNA virus models

\section{INTRODUCTION}

The major components of honey bee venom-mellitin, phospholipase A2, and hyaluronidase-appear to be present in similar concentrations in both European and Africanized bee venom (Schumacher, 1993) The most important component is the peptide mellitin, which comprises approximately 50\% of bee venom (McKenna, 1993). Bee venom has antibacterial, antiparasitidal, and antiviral properties 
(Guillaume et al., 2006). Secreted phospholipases A2 (PLA2) from bee and snake venoms have potent anti-human immunodeficiency virus (HIV) activities. These PLA2s block HIV-1 entry into host cells through a mechanism linked to PLA2 binding to cells (Fenard et al., 2001).

\section{MATERIALS AND METHODS}

\section{1- COLONIZATION OF HONEY BEE:-}

The colonization was conducted at the apiaries of Plant Protection Department, Faculty of Agriculture, Ain Shams University for one year to produce the honey bee venom used in this work.

\section{2- EXTRACTION OF HONEY BEE VENOM:-}

According to Mraz, (1983) the electrical shock method has been used to stimulate the bees to sting. The collector frame placed at the entrance of the hive and connected to a device which supplies electrical impulses, when bees receive a mild electric shock up 33 volts ; They sting the surface of the collector sheet as they see this to be the source of danger. The deposited venom between the glass and the protective material was dried then later scrapped off by a razor blade and collected in a dark bottle in a powder form.

\section{3-PREPARATION OF THE VERO CELL LINE:-}

Vero cell line, derived from the kidney of a normal, adult, African green monkey, (American tissue culture collection, USA, supplied by tissue culture department, VACSERA) was grown in MEM EARLES medium supplemented with $10 \%$ fetal calf serum (FCS)(GEPCO, USA), $100 \mu \mathrm{g} / \mathrm{ml}$ penicillin and $10 \mu \mathrm{g} / \mathrm{ml}$ streptomycin. Fully grown monolayer was selected and the cells were trypsinized (Trypsin 0.25\%, (Sigma, USA). Cell suspension was dispensed as $100 \mu \mathrm{l} /$ well using automatic micropipette 20-200 $\mu$ l (Eppendorph - Germany) in 96 well tissue culture plates (gamma sterilized, tissue culture treated, TPP, made in Europe/ SWITZELAND). Then plates were incubated at $37{ }^{\circ} \mathrm{C}$ (Double door incubator. Jouan, France) till confluent sheet was microscopically detected using inverted microscope (Willovert, Germany).

\section{4- DETERMINATION OF MODEL VIRUSES INFECTIVITY}

\section{TITER:-}

After discarding of the growth media (MEM EARLES medium supplemented with $10 \%$ fetal calf serum FCS,GEPCO, USA, $100 \mu \mathrm{g} / \mathrm{ml}$ penicillin and $10 \mu \mathrm{g} / \mathrm{ml}$ streptomycin) from the 96 well tissue culture plates, inoculated using 10 fold dilution of virus models: - (West Nile virus as RNA model and human Adenovirus sero-type 7(adeno-7) and Herpes simplex virus type I (HSV-1) as a DNA models) supplied by Dr. Aly Fahmy, virology sector, rabies research unit, VACSERA), $100 \mu \mathrm{l} /$ well and sealed with sterile sealer (Flow laboratories, USA) then incubated at $37^{\circ} \mathrm{C}$. Plates were incubated for 7 days with daily microscopic examination for the detection of cellular degeneration (cytopathic effect CPE). Viral infectivity titer was evaluated according to the method adopted by (Reed and Muench, 1938).

\section{5- VIRUCIDAL ACTIVITY}

Virucidal activity of bee venom was conducted according to Aoki and Messiha, (1999) where $0.5 \mathrm{ml}$ of the virus was mixed with $0.5 \mathrm{ml}$ of bee venom solution $(100 \mu \mathrm{g} / \mathrm{ml})$ virus control set was included where the virus was mixed with bee venom free medium, both sets were incubated at $37^{\circ} \mathrm{C}$ for 3,6 and 24 hours. The mean virus titers were determined in a duplicate post time intervals using cell culture inoculation assay (CCIA) or the CCID $_{50}$ as previous. The inhibitory effect of bee 
venom was determined by using the probability associated with a Student's t-Test. The virus titer depletion was expressed as $\mathrm{X} \log (10) / 0.1 \mathrm{ml}$.

\section{6- Antiviral Activity}

Antiviral activity of bee venom on West Nile virus (WNV), Adenovirus type 7 (adeno-7) and Herpes simplex virus type 1 (HSV - I) was determined to evaluate the infectivity titer in Vero cells According to Aoki and Messiha, (1999) where confluent monolayer of Vero cells in 96-well tissue culture plates (TPP-Swiss), were divided into two sets, the first was treated with the safe concentration of bee venom (adding $100 \mu \mathrm{l} /$ well) then incubated at $37^{\circ} \mathrm{C}$ at the following intervals; 3, 6 and 24 hours and the other set was treated with bee venom free media and incubated for the same intervals as a negative cell control, then media of the two sets were discarded after each incubation interval and inoculated at $37^{\circ} \mathrm{C}$ with the different virus models. CCID $_{50}$ was determined according to the method adopted by Reed and Muench, (1938).

\section{7-COMPARISON OF THE ANTIVIRAL ACTIVITY OF BEE VENOM WITH INTERFERON}

Vero Cells at a concentration of $2 \times 10^{5}$ cells/ml were maintained to confluence in 96 well cell culture plates. Four rows of the cultured cells were treated with 100 IU/well of interferon (pegintron $80 \mathrm{mg} / 0.5$ (800.000 IU/mg), Shering-Plough, USA) and the rest of the plate was supplemented with interferon (IFN) free media. Plates were incubated for $24 \mathrm{hrs}$. at $37^{\circ} \mathrm{C}$. The media was discarded and wells were inoculated with 10 fold serially diluted virus models (WNV, Adeno-7 and HSV-I) and incubated at $37^{\circ} \mathrm{C}$ for 7 days. A 96 well cell culture plate for each virus was used according to (Denizot and Lang, 1986). CCID $_{50}$ was determined according to the method adopted by (Reed and Muench, 1938). Antiviral activity of bee venom which achieved according to (Chatis and Crumpacker, 1992) was compared to the method described by (Denizot and Lang, 1986) where, the difference between the mean virus infectivity titer inoculated on INF treated and non-treated cells as a negative control was compared to the difference between the mean virus infectivity titer detected post inoculation of bee venom treated and non-treated cells. The virus titer depletion was expressed as $\mathrm{X} \log (10) / 0.1 \mathrm{ml}$.

\section{RESULTS AND DISCUSSION}

\section{1) VIRUCIDAL ACTIVITY}

Virucidal activity of bee venom against Herpes simplex virus type 1(HSV-1) as a DNA model virus was carried out concerning the time interval of virus - venom exposure and it was clear that there was no significant decrease in HSV-1 infectivity titer 3 hours post treatment recording $6.75 \log (10) / 0.1 \mathrm{ml}$ compared with the nontreated virus control infectivity titer recording $6.8 \mathrm{log}(10) / 0.1 \mathrm{ml}$. Also, the virus infectivity titer recorded 6 hours post treatment was $6.71 \log (10) / 0.1 \mathrm{ml}$ and the set virus control infectivity titer was $6.79 \log (10)$. In the same time the virus infectivity titer 24 hours post treatment was $6.0 \log (10) / 0.1 \mathrm{ml}$ and the non-treated virus infectivity titer was $6.5 \log (10) / 0.1 \mathrm{ml}$. The significant decrease in the HSV-1 infectivity titer was detected 48 hours post treatment and the titer recording 1.0 log (10) table (1) and figure (1).

Also, virucidal activity of bee venom against Adeno virus serotype 7 (Adeno7) as another available model DNA virus was carried out concerning the time interval of virus - venom exposure and it was clear that there was no significant decrease in Adenovirus-7 infectivity titer 3 hours post treatment recording $4.75 \log (10) / 0.1 \mathrm{ml}$ 
compared with the non-treated virus control infectivity titer recording 5.1log (10)/0.1ml $(\mathrm{P}<0.05)$.

Table (1) Evaluation of the mean virucidal activity of bee venom against HSV-1Using cell culture inoculation assay (CCIA) compared to virus control

\begin{tabular}{|c|c|c|c|c|c|c|c|}
\hline $\begin{array}{c}\text { Time post } \\
\text { treatment / hour }\end{array}$ & \multicolumn{2}{|c|}{$\begin{array}{c}\text { virus control } \\
\text { titers } \log (10) \\
\quad / 0.1 \mathrm{ml}\end{array}$} & \multirow{2}{*}{$\begin{array}{c}\text { Mean } \\
6.80\end{array}$} & \multicolumn{2}{|c|}{$\begin{array}{l}\text { Bee venom treated } \\
\text { virus } \log (10) / 0.1 \mathrm{ml}\end{array}$} & \multirow{2}{*}{$\begin{array}{r}\text { Mean } \\
6.80\end{array}$} & \multirow{2}{*}{$\begin{array}{c}\text { P value } \\
>0.05\end{array}$} \\
\hline control & 6.70 & 6.90 & & 6.80 & 6.80 & & \\
\hline 3 & 6.80 & 6.80 & 6.80 & 6.60 & 6.90 & 6.75 & $>0.05$ \\
\hline 6 & 6.7 & 6.88 & 6.79 & 6.70 & 6.72 & 6.71 & $>0.05$ \\
\hline 24 & 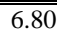 & 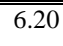 & " 6.50 & "6.30 & $\begin{array}{c}5.70 \\
\end{array}$ & 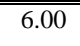 & $>0.05$ \\
\hline 48 & 3.00 & 3.38 & 3.19 & 0.70 & 1.30 & 1.00 & $<0.05$ \\
\hline
\end{tabular}

$\mathrm{p}>0.05$ by Student's t-test (non significant) $\mathrm{p}<0.05$ by Student's t-test (significant)

Figure (1) Virucidal activity of bee venom against Ade no Virus-7

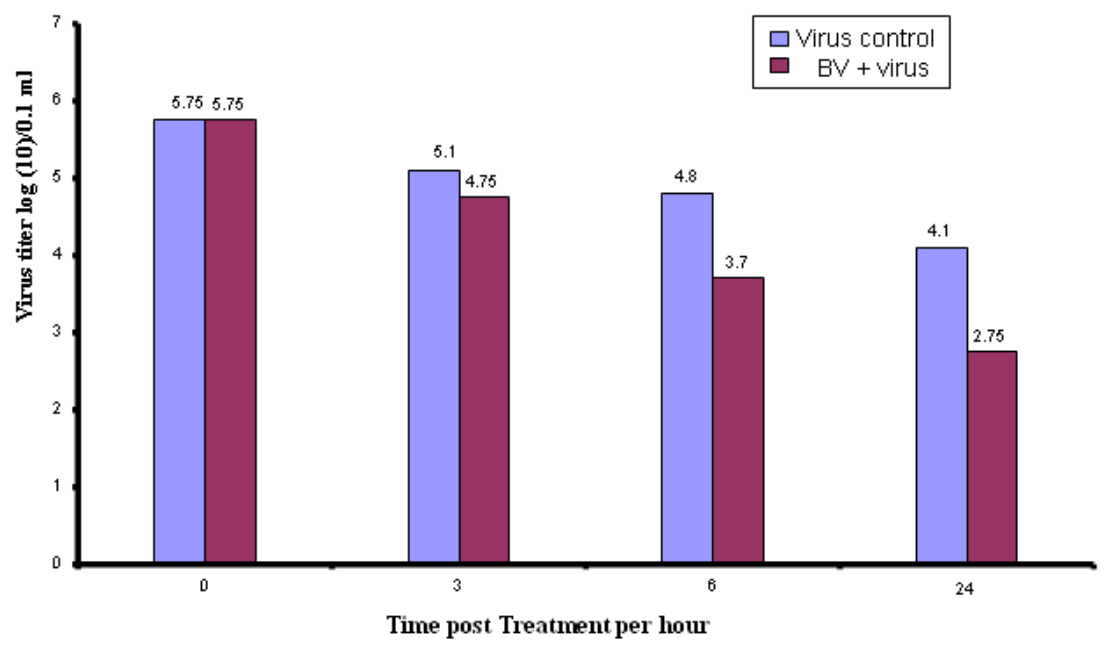

Also, a significant depletion rate of virus infectivity titer was noticed, as the virus infectivity titer recording $3.7 \log (10) / 0.1 \mathrm{ml} 6$ hours post treatment compared with the non-treated virus control infectivity titer recording $4.8 \log (10)$; $(\mathrm{P}<0.05)$.In the same time a significant depletion rate of virus infectivity titer was recorded 24 hours post treatment recording $2.75 \log (10) / 0.1 \mathrm{ml}$, table (2) and figure (2).

Evaluation of the virucidal activity of bee venom against RNA model virus; West Nile virus (WNV) was carried out concerning the time interval of virus - venom exposure and it was clear that there was a significant depletion in West Nile virus 
infectivity titer 3 hours post treatment recording $5.1 \log (10) / 0.1 \mathrm{ml}$ compared with the non-treated virus control infectivity titer recording $6.7 \log (10) / 0.1 \mathrm{ml}(\mathrm{P}<0.05)$.

Table (2) Evaluation of the mean virucidal activity of bee venom against Adenovirus-7 Using cell culture inoculation assay (CCIA) compared to virus control

\begin{tabular}{|c|c|c|c|c|c|c|c|}
\hline $\begin{array}{l}\text { Time post } \\
\text { treatment / } \\
\text { hour }\end{array}$ & $\begin{array}{l}\text { viru } \\
\log (1\end{array}$ & trol & Mean & $\begin{array}{l}\text { Bee ven } \\
\text { virus lo }\end{array}$ & $\begin{array}{l}\text { eated } \\
0.1 \mathrm{ml}\end{array}$ & Mean & $P$ value \\
\hline control & 5.50 & 6.00 & 5.75 & 5.80 & 5.70 & 5.75 & $>0.05$ \\
\hline 3 & 4.80 & 5.40 & 5.10 & 4.50 & 5.00 & 4.75 & $>0.05$ \\
\hline 6 & 4.70 & 4.90 & 4.80 & 3.50 & 3.90 & 3.70 & $<0.05$ \\
\hline 24 & 4.50 & 3.70 & 4.10 & 2.75 & 2.75 & 2.75 & $<0.05$ \\
\hline
\end{tabular}

$\mathrm{p}>0.05$ by Student's t-test (non significant)

$\mathrm{p}<0.05$ by Student's t-test (significant)

Figure (2) Virucidal activity of bee venom against West Nile Virs

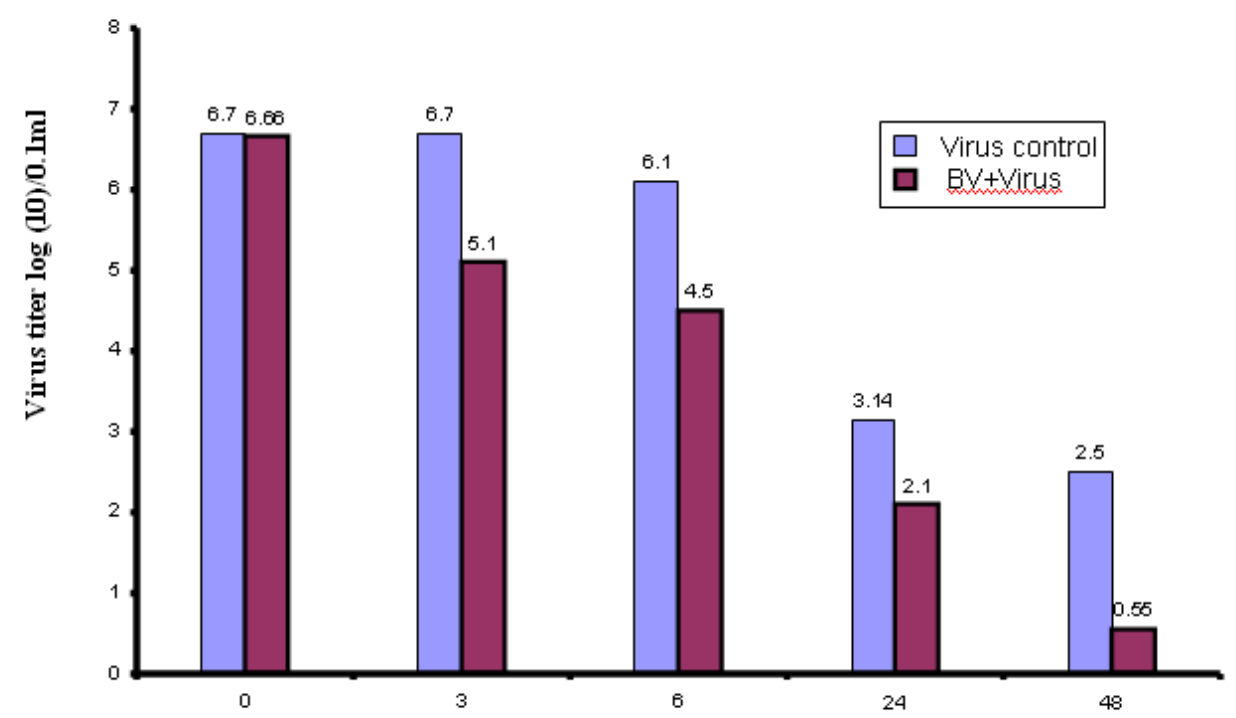

Time post Treatment per hour

Also, a significant depletion rate of virus infectivity titer was noticed, as the virus infectivity titer recorded 6 hours post treatment was $4.5 \log (10) / 0.1 \mathrm{ml}$ compared with the non-treated virus control infectivity titer recording $6.1 \log (10)$; ( $\mathrm{P}$ $<0.05)$. In the same time a significant depletion rate of virus infectivity titer recorded 24 hours post treatment was $2.1 \log (10) / 0.1 \mathrm{ml}$ and that of the non-treated virus infectivity titer was $3.14 \log (10) / 0.1 \mathrm{ml} ;(\mathrm{P}<0.05)$ table (3) and figure (3).

These results were in agreement with Filotti et al., (1967) who stated that the presence of virucidal activity on or inactivation of rabies virus by bee venom was noticed 24 hours post treatment. Also, Lawrence and Skalka, (1980) stated that the melittin compound can make the viral envelope permeable, that make it lose of its infectivity. 
De-Clercq et al., (2000) proved that bee venom melittin inactivates HIV and also aborts cell-to-cell fusion and transmission of HIV, due to its high-affinity interaction with gp120 and Mitsuishi et al., (2006) indicated that the direct addition of bee venom phospholipase A2 to 293A cells suppressed adenovirus plaque formation in both number and size.

Table (3) Evaluation of the mean virucidal activity of bee venom against WNV Using cell culture inoculation assay (CCIA) compared to virus control

\begin{tabular}{|c|c|c|c|c|c|c|c|}
\hline \multirow{2}{*}{$\begin{array}{c}\begin{array}{c}\text { Time post } \\
\text { treatment per } \\
\text { hour }\end{array} \\
\\
\text { control }\end{array}$} & \multicolumn{2}{|c|}{$\begin{array}{l}\text { virus control titers } \\
\log (10) / 0.1 \mathrm{ml}\end{array}$} & \multirow{2}{*}{$\begin{array}{c}\text { Mean } \\
6.70\end{array}$} & \multicolumn{2}{|c|}{$\begin{array}{c}\text { Bee venom } \\
\text { treated virus log } \\
(10) / 0.1 \mathrm{ml}\end{array}$} & \multirow{2}{*}{$\begin{array}{r}\text { Mean } \\
6.66\end{array}$} & \multirow{2}{*}{$\begin{array}{l}\text { P value } \\
>0.05\end{array}$} \\
\hline & 6.60 & 6.80 & & 6.50 & 6.82 & & \\
\hline 3 & 6.50 & 6.90 & 6.70 & 5.10 & 5.10 & 5.10 & $<0.05$ \\
\hline 6 & 6.20 & 6.00 & 6.10 & 4.40 & 4.60 & 4.50 & $<0.05$ \\
\hline 24 & 2.84 & 3.44 & 3.14 & 2.00 & 2.20 & 2.10 & $<0.05$ \\
\hline
\end{tabular}

p>0.05 by Student's t-test (non significant)

$\mathrm{p}<0.05$ by Student's t-test (significant)

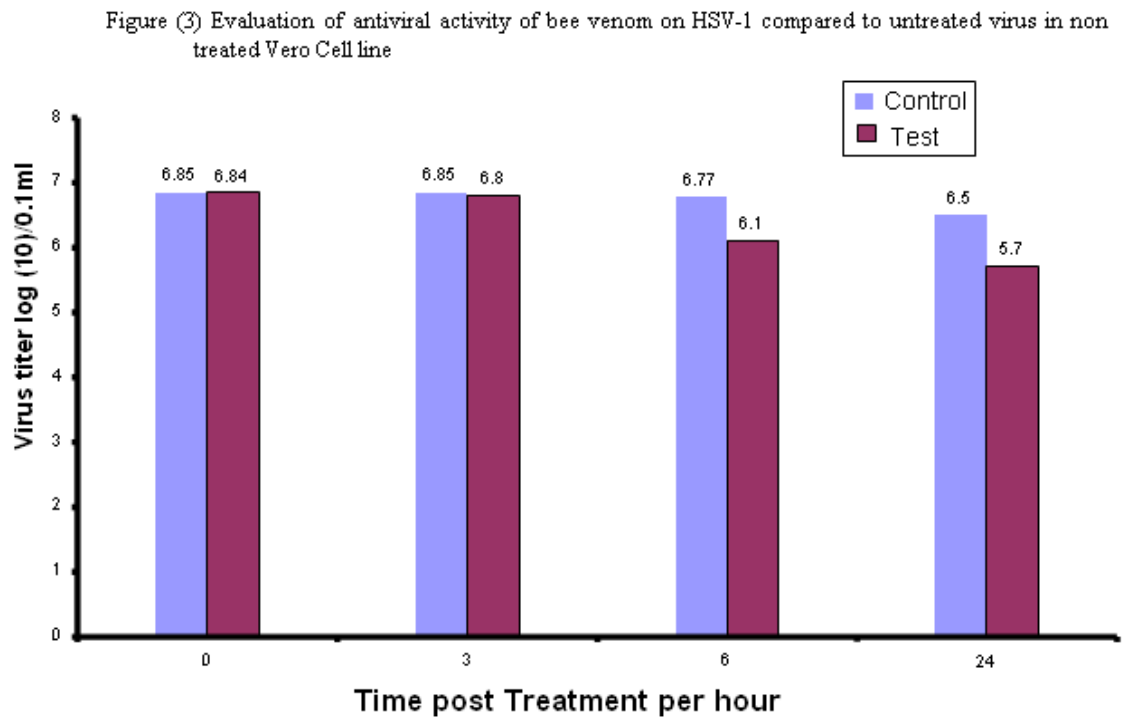

\section{2) Antiviral ACtivity:-}

Antiviral activity was carried out according to Aoki and Messiha, (1999), where two DNA virus models were used; Herpes simplex virus type -1 (HSV-1) and Adenovirus serotype 7(Adeno-7). The infectivity titer of bee venom treated virus for 3 hrs at $37^{\circ} \mathrm{C}$ was non significantly influenced $(\mathrm{P}>0.05)$ recording a depletion rate of virus infectivity titer where the virus titer of bee venom treated and non treated was $6.8 \log (10) / 0.1 \mathrm{ml}$ and $6.85 \log (10) / 0.1 \mathrm{ml}$ respectively. Also, a non significant depleted infectivity titer was noticed 6 hrs post bee venom treatment compared with bee venom nontreated virus as a control recording $6.1 \log (10) / 0.1 \mathrm{ml}$ and $6.77 \mathrm{log}$ (10) $/ 0.1 \mathrm{ml}$ respectively $(\mathrm{P}>0.05)$. Also a non-significant decreased virus infectivity titer was recorded post 24 hrs treatments where the bee venom treated and non treated 
virus infectivity titer was $5.7 \log (10) / 01 \mathrm{ml}$ and $6.5 \log (10) / 0.1 \mathrm{ml}$ respectively ( $\mathrm{P}>0.05)$. Table (4) and figure (4).

Table (4) Antiviral activity of bee venom on Herpes simplex virus type-1 Herpes simplex virus type-1

\begin{tabular}{|c|c|c|c|c|c|c|c|}
\hline \multirow{2}{*}{$\begin{array}{c}\begin{array}{c}\text { Time post } \\
\text { treatment } \\
\text { per hour }\end{array} \\
\text { control }\end{array}$} & \multicolumn{2}{|c|}{$\begin{array}{l}\text { virus control titers } \\
\log (10) / 0.1 \mathrm{ml}\end{array}$} & \multirow{2}{*}{$\begin{array}{c}\text { Mean } \\
6.85\end{array}$} & \multicolumn{2}{|c|}{$\begin{array}{l}\text { Bee venom treated } \\
\text { virus } \log (10) / 0.1 \mathrm{ml}\end{array}$} & \multirow{2}{*}{$\begin{array}{c}\text { Mean } \\
6.84\end{array}$} & \multirow{2}{*}{$\begin{array}{c}\text { P value } \\
>0.05\end{array}$} \\
\hline & 6.80 & 6.90 & & 6.80 & 6.88 & & \\
\hline 3 & 6.85 & 6.85 & 6.85 & 7.00 & 6.60 & 6.80 & $>0.05$ \\
\hline 6 & 6.20 & 7.34 & 6.77 & 6.00 & 6.20 & 6.10 & $>0.05$ \\
\hline 24 & 6.60 & 6.40 & 6.50 & 6.30 & 5.10 & 5.70 & $>0.05$ \\
\hline
\end{tabular}

Figure (4) Evaluation of antiviral activity of bee venom on Adenovirus -7 compared to untreated virus in non treated vero Cell line

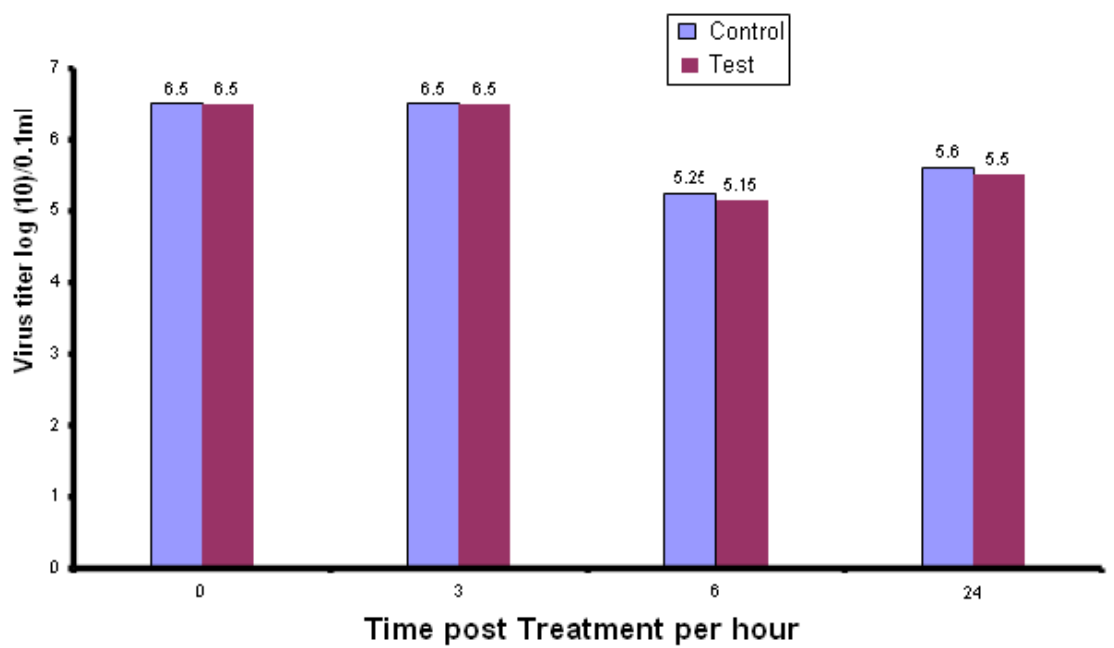

The antiviral activity was achieved using Adenovirus serotype 7 was used as a $2^{\text {nd }}$ DNA model virus where the infectivity showed no change relatively to the time of exposure to bee venom at $37^{\circ} \mathrm{C}$ where the virus infectivity titer either bee venom treated and non treated showed the same value recording $6.5 \log (10) / 0.1 \mathrm{ml} 3$ hours post treatment. While, 6 hours post treatment the virus infectivity titer was $5.15 \mathrm{log}$ (10) and $5.25 \log (10)$ for virus bee venom treated and non treated respectively. In the same time virus infectivity titer detected 24 hrs post treatment revealed that the virus infectivity titer was $5.5 \log (10) / 0.1 \mathrm{ml}$ and $5.6 \log (10) / 0.1 \mathrm{ml}$ for control non-treated virus indicating a non significant decrease in virus titer. Table (5) and figure (5). 
Table (5) Antiviral activity of Bee venom on Adenovirus serotype 7

\begin{tabular}{|c|c|c|c|c|c|c|c|}
\hline $\begin{array}{l}\text { Time post } \\
\text { treatment per }\end{array}$ & $\begin{array}{r}\text { virus c } \\
\log (1\end{array}$ & $\begin{array}{l}\text { l titer } \mathrm{s} \\
1 \mathrm{ml}\end{array}$ & Mean & $\begin{array}{r}\text { Bee ven } \\
\text { titer }\end{array}$ & $\begin{array}{l}\text { ed virus } \\
.1 \mathrm{ml}\end{array}$ & Mean & $P$ value \\
\hline control & 6.60 & 6.40 & 6.50 & 6.50 & 6.50 & 6.50 & $>0.05$ \\
\hline 3 & 6.70 & 6.30 & 6.50 & 6.10 & 6.90 & 6.50 & $>0.05$ \\
\hline 6 & 5.25 & 5.25 & 5.25 & 5.00 & 5.30 & 5.15 & $>0.05$ \\
\hline 24 & 5.20 & 6.00 & 5.60 & 5.55 & 5.45 & 5.50 & $>0.05$ \\
\hline
\end{tabular}

$\mathrm{p}>0.05$ by Student's t-test (non significant)

$\mathrm{p}<0.05$ by Student's t-test (significant)

Figure (5) Evaluation of antiviral activity of Bee venom on WWU compared to untreated virus in non treated vero Cell line

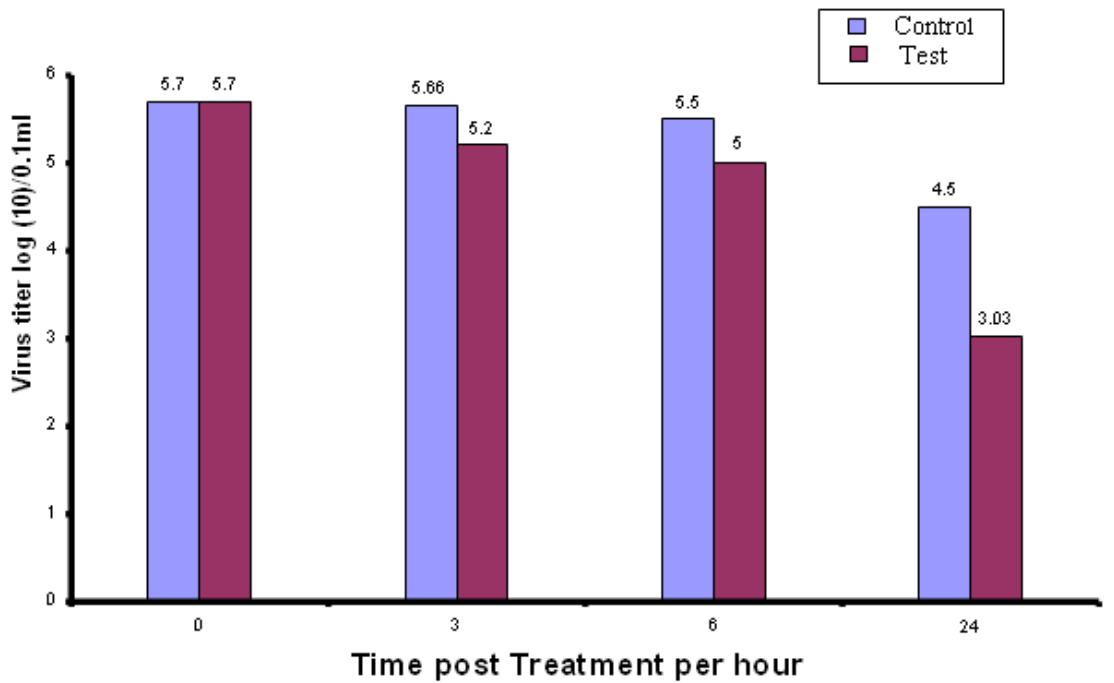

The antiviral activity testing of west Nile virus revealed that virus infectivity titer showed non significant change in case of evaluation of bee venon treated and non - treated virus recording infectivity titer was $3 \log (10) 0.1 \mathrm{ml} 4.5 \log (10) 0.1 \mathrm{ml}$ respectively post bee venom treatment at 37c and $4.5 \log (10) 0.1 \mathrm{ml}$ in case of bee venom non treated virsus table (6) and figure (6).

These results were not coinciding with the data recorded by Baier et al., (2000); they recorded that nasal application of lipopeptide increased protection against a lethal infection of influenza. Also, Masuda et al., (2005) explained that the antiviral effect of the bee venom phospholipase A2 depends essentially on its ability to hydrolyze phospholipids in host cell membranes Also proved that Bee venom 
melittin inactivates HIV and also aborts cell-to-cell fusion and transmission of HIV, due to its high-affinity interaction with gp120.

Table (6) Antiviral activity of Bee venom on West Nile Virus

\begin{tabular}{|c|c|c|c|c|c|c|c|}
\hline \multirow{2}{*}{$\begin{array}{c}\begin{array}{c}\text { Time post } \\
\text { treatment } \\
\text { per hour }\end{array} \\
\text { control }\end{array}$} & \multicolumn{2}{|c|}{$\begin{array}{l}\text { virus control titers } \\
\log (10) / 0.1 \mathrm{ml}\end{array}$} & \multirow{2}{*}{$\begin{array}{c}\text { Mean } \\
5.70\end{array}$} & \multicolumn{2}{|c|}{$\begin{array}{l}\text { Bee venom treated } \\
\text { virus } \log (10) / 0.1 \mathrm{ml}\end{array}$} & \multirow{2}{*}{$\begin{array}{c}\text { Mean } \\
5.70\end{array}$} & \multirow{2}{*}{$\begin{array}{c}\text { P value } \\
>0.05\end{array}$} \\
\hline & 5.50 & 5.90 & & 5.70 & 5.70 & & \\
\hline 3 & 4.85 & 6.47 & 5.66 & 5.20 & 5.20 & 5.20 & $>0.05$ \\
\hline 6 & 5.10 & 5.90 & 5.50 & 5.67 & 4.33 & 5.00 & $>0.05$ \\
\hline 24 & 4.51 & 4.49 & 4.50 & 3.1 & 2.9 & 3.0 & $>0.05$ \\
\hline
\end{tabular}

$\mathrm{p}>0.05$ by Student's t-test (non significant)

$\mathrm{p}<0.05$ by Student's t-test (significant)

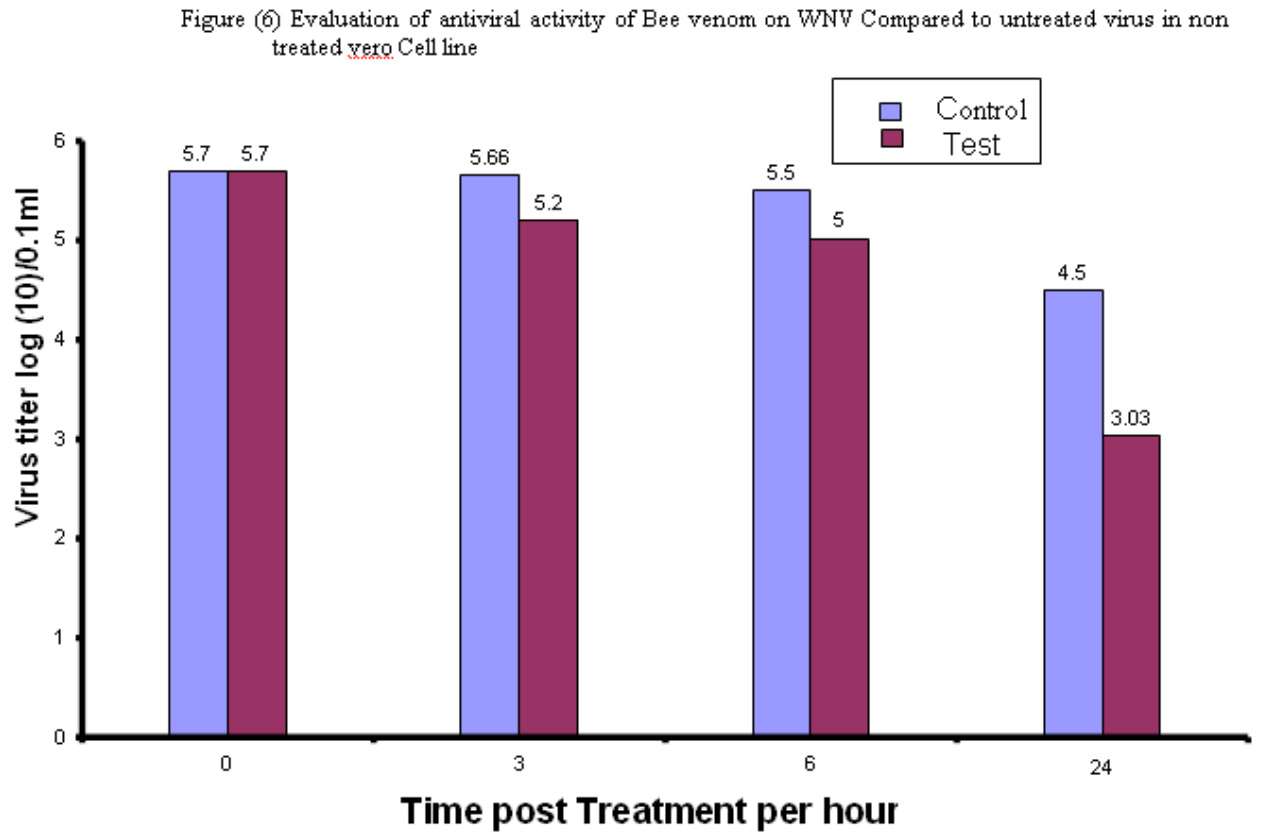

3) COMPARISON OF THE ANTIVIRAL ACTIVITY OF BEE VENOM With THAT OF INTERFERON

Antiviral activity of bee venom was compared with that of the standard antiviral drug; interferon $\boldsymbol{x}-2$ a (IFN - $\boldsymbol{\alpha}$ 2a).The first DNA model virus; HSV-1 was of infectivity titer recording $5.5 \log (10) / 0.1 \mathrm{ml}$ in the bee venom treated cells compared to the virus control infectivity titer on bee venom non treated cells $5.9 \log (10) / 0.1 \mathrm{ml}$ recording a difference in the order of $0.4 \log (10) / 0.1 \mathrm{ml}$, revealing a non significant depletion of virus infectivity titer $(\mathrm{P}>0.5)$, While the virus infectivity titer showed a significant decrease in recording $3.2 \log (10) / 0.1 \mathrm{ml}(\mathrm{P}<0.05)$. Table (7). 
Table (7) Comparison of the antiviral activity of Bee venom with that of interferon

\begin{tabular}{|c|c|c|c|c|c|c|c|c|c|c|c|c|c|}
\hline \multirow{2}{*}{$\begin{array}{c}\text { Virus model } \\
\begin{array}{c}\text { Herpes simplex } \\
\text { virus type } 1\end{array}\end{array}$} & \multicolumn{2}{|c|}{$\begin{array}{l}\text { virus control } \\
\log (10) / 0.1 \mathrm{ml}\end{array}$} & \multirow{2}{*}{$\begin{array}{c}\text { Mean } \\
5.9\end{array}$} & \multicolumn{2}{|c|}{$\begin{array}{c}\text { interferon } \\
\text { treated } \\
\text { virus log } \\
(10) / 0.1 \mathrm{ml} \\
\end{array}$} & \multirow{2}{*}{$\begin{array}{c}\text { Mean } \\
3.2\end{array}$} & \multirow{2}{*}{$\begin{array}{c}\begin{array}{c}\text { P } \\
\text { value }\end{array} \\
\\
<0.05\end{array}$} & \multirow{2}{*}{$\begin{array}{c}\begin{array}{c}\text { Depletion } \\
\text { titer } \\
\log (10) / 0.1 \\
\mathrm{ml}\end{array} \\
\\
2.7\end{array}$} & \multicolumn{2}{|c|}{$\begin{array}{l}\text { bee venom } \\
\text { treated virus } \\
\log (10) / 0.1 \mathrm{ml}\end{array}$} & \multirow{2}{*}{$\begin{array}{c}\text { Mean } \\
5.5\end{array}$} & \multirow{2}{*}{$\begin{array}{c}\begin{array}{c}P \\
\text { value }\end{array} \\
>0.05\end{array}$} & \multirow{2}{*}{$\begin{array}{c}\begin{array}{c}\text { Depletion } \\
\text { titer } \\
\log (10) / 0.1 \mathrm{ml}\end{array} \\
0.4\end{array}$} \\
\hline & 6.0 & 5.8 & & 3.0 & 3.4 & & & & 5.4 & 5.6 & & & \\
\hline $\begin{array}{c}\text { Adenovirus } \\
\text { serotype } 7 \\
\end{array}$ & 6.4 & 6.8 & 6.6 & 3.2 & 3.3 & 3.25 & $<0.05$ & 3.35 & 3.30 & 3.50 & 3.4 & $<0.05$ & 3.2 \\
\hline $\begin{array}{c}\text { West Nile } \\
\text { Virus } \\
\end{array}$ & 4.0 & 4.2 & 4.1 & 2.5 & 2.5 & 2.5 & $<0.05$ & 1.6 & 1.10 & 0.90 & 1.0 & $<0.05$ & 3.1 \\
\hline
\end{tabular}

This data revealed the priority of antiviral activity of IFN than bee venom in the viral infection treatment and resemblance to that reported by Costa da Cunha et al, (1996) who approved that Interferon alpha (IFN- $\boldsymbol{\alpha}$ ) has been successfully used in treatment of various clinical forms of Kaposi's sarcoma KS, including AIDS-KS and $\mathrm{C}-\mathrm{KS}$, those were associated with (HHV-8) infections In the mean time antiviral activity against adenovirus-7 revealed a decrease of viral infectivity titer in the order of $3.4 \log (10) / 0.1 \mathrm{ml}$ post bee venom compared with the virus control infectivity titer; $6.6 \log (10) / 0.1 \mathrm{ml}$ recording a depletion of infectivity titer in the order of 3.2 $\log (10) / 0.1 \mathrm{ml}$. While use of IFN showed a titer of $3.25 \log (10) / 0.1 \mathrm{ml}$ post IFN treatment compared with the virus control infectivity titer; $6.6 \log (10) / 0.1 \mathrm{ml}$ recording a depletion of infectivity titer in the order of $3.35 \log (10) / 0.1 \mathrm{ml}$. This means that in vitro studies indicate the almost the resemblance of the effect of standard IFN and bee venom on the Adenovirus-7 The recorded data were in parallel to those recorded by Samuel, (2001) who reported that Interferon-alpha (IFN-a) has broad antiviral activity in vitro and immunostimulatory effects in vivo.

West Nile virus (WNV )as RNA model virus was well influenced by bee venom better than IFN where the virus infectivity titer recorded post bee venom treatment was $1 \log (10) / 0.1 \mathrm{ml}$ and revealing a depletion rate in the order of $3.1 \mathrm{log}$ (10) $/ 0.1 \mathrm{ml}$ in comparison to the virus control titer. While, the infectivity titer post IFN treatment was $2.5 \log (10) / 0.1 \mathrm{ml}$ revealing a depletion rate in the order of $1.6 \mathrm{log}$ (10) $/ 0.1 \mathrm{ml}$ than the virus control titer $4.1 \mathrm{log}(10) / 0.1 \mathrm{ml}$ table (7) Anderson and Rahal, (2002) reported that interferon- alpha has been considered to be a possible therapy for flaviviral encephalitis. Interferon- alpha has been shown to have in vitro activity against West Nile virus in a Vero cell model. Also, Fahmy and Shoman, (2006) reported that the therapeutic role of recombinant human interferon alpha (rhIFN- $\alpha$ ) was evaluated to control rift valley fever (RVF), and they concluded that IFN could be used to share and integrate the control program of RVF viral infection.

\section{REFERENCES}

Anderson J F. and Rahal J. J. (2002). Efficacy of interferon alpha-2b and ribavirin against West Nile virus in vitro. Emerg Infect Dis.; 8:107-8.

Aoki, F.Y. and Messiha, N. (1999). Assessing In Vitro Herpes Simplex Inhibitory Activity of Stannous Fluoride, Embro Research Corporation. W. J .Embro, DDS, Manitoba University, Canada 
Baier,-W; Masihi,-N; Huber,-M; Hoffmann,-P and Bessler,-W-G. (2000). Lipopeptides as immunoadjuvants and immunostimulants in mucosal immunization. Immun., 201(3-4): 391-405.

Chatis P.A. and Crumpacker CS. (1992). Resistance of herpesviruses to antiviral drugs. Antimicrob Agents Chemother 36:1589 - 95.

Costa da Cunha, C. S.; Lebbe, C.; Rybojad, M.; Agbalika, F.; Ferchal, F.; Rabian, C.; Vignon-Pennamen, M. D.; Calvo, F. and Morel, P. (1996). Long-term follow-up of non-HIV Kaposi's sarcoma treated with low-dose recombinant interferon alfa-2b. Arch. Dermatol. 132:285-290.

Denizot, F. and Lang, R. (1986). Rapid colorimetric assay for cell growth and survival. J. of Immunol. Methods 89: 271-277.

Fahmy, A. M. and Shoman, S. A. (2006). Antiviral Activity of recombinant Human Interferon $\alpha$ to Rift Valley Fever Virusand Related Mx-Protein Potential as a Biomarker. E. J. Biomed. Sci. 21.

Fenard, D.; Lambeau, G.; Maurin, T.; Lefebvre, J.C.; and Doglio, A. (2001). A peptide derived from bee venom-secreted phospholipase A2 inhibits replication of T-cell tropic HIV- 1 strains via interaction with the CXCR4 chemokine receptor. Mol. Pharmacol. 60:341-347

Filotti, A.; Derevici, E. T. (1967). Action of bee venom on fixed rabies virus - Arch Roum Pathol Exp Microbiol.

Guillaume C.; Calzada C.; Lagarde M.; Schrével J. and Deregnaucourt C. (2006). Interplay between lipoproteins and bee venom phospholipase A2 in relation to their anti-plasmodium toxicity. J. Lipid Res., 47: 1493 - 1506.

Lawrence R. B. and Skalka, A. (1980). Two species of full-length cDNA are synthesized in high yield by melittin-treated avian retrovirus particles. Proc. Nati. Acad. Sci. USA 77(2): 847-851.

Masuda, S.; Murakami, M.; Takanezawa, Y.; Aoki, J.; Arai, H.; Ishikawa, Y.; Ishii, T.; Arioka, M. and Kudo, I.. (2005). Neuronal expression and neuritogenic action of group X secreted phospholipaseA2. J. Biol. Chem. 280: 2320323214.

McKenna, W. (1993). killer bees: what the allergist should know. Pediatr. Asthma allergy and immunol; 6:275-285.

Mitsuishi M.; Masuda S.; Kudo I. and Murakami, M. (2006). Group V and X secretory phospholipase A2 prevents adenoviral infection in mammalian cells. Biochem J.; 393(Pt 1):97-106.

Mraz, C. (1983). Methods of collecting bee venom and its utilization. Apiacta, 18: (33): 34-54.

Reed, L. J., and H. Muench. (1938). A simple method of estimating 50 per cent endpoints. Amer. Jour. Hygiene, 27: 493-497.

Samuel CE. (2001). Antiviral actions of interferons. Clin Microbiol Rev.;14:778-809.

Schumacher, M. J. (1993). Significance of Africanized bees for public health. Arch Med Intern; 155:2038-2043. 


\section{RABIC SUMMARY \\ دراسات بيولوجيه لتقييم قدرة سم النحل المضادة للفيروسات باستخدام نماذج من فيروسات رييوزيه و ديؤكسي رييوزيه \\ روحية حسن رمضان 1 - على فهمى محمد² - محمد صلاح عبد الدايم²

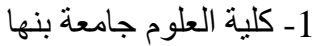 \\ 2- الشركة القابضة للمستحضر ات الحيومية واللقاحات (فاكسيرا)}

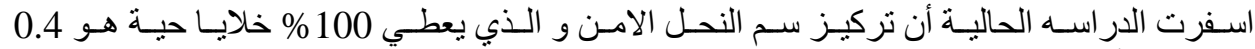

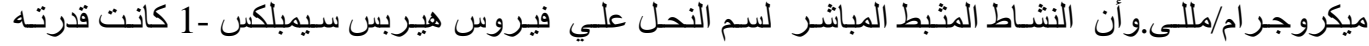

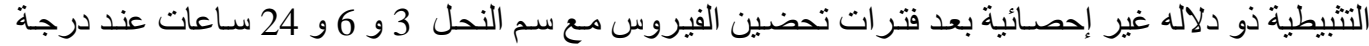

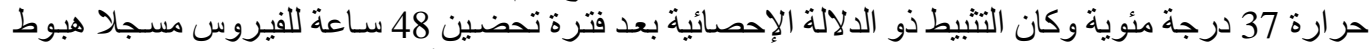

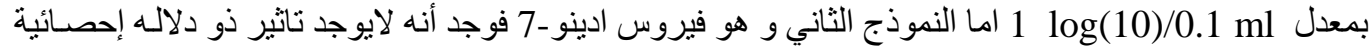

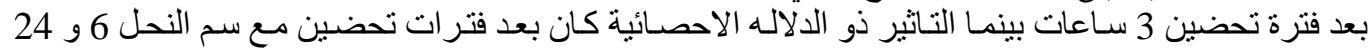
سـاعة مستجلا هبوط في تركيز الفيروس بمعدل

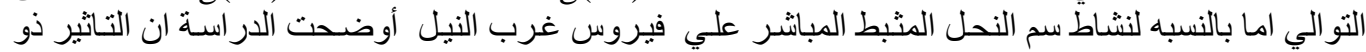

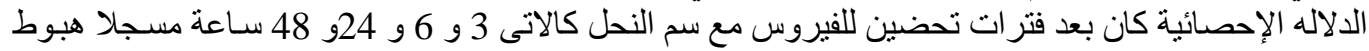
في تركيز الفيروس بمعدل 0.55 log (10)/0.1 ml

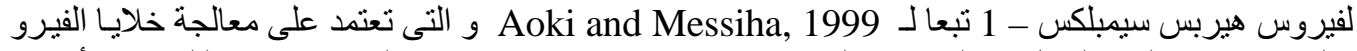

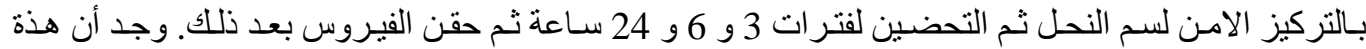

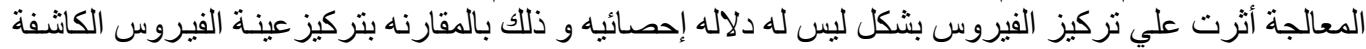

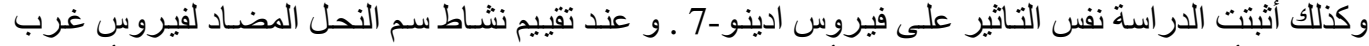

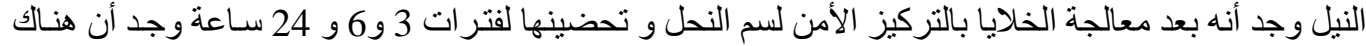

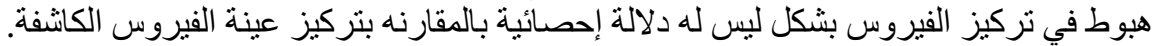

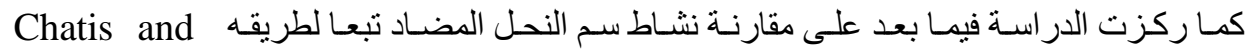

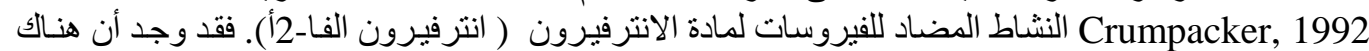

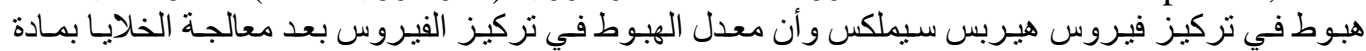

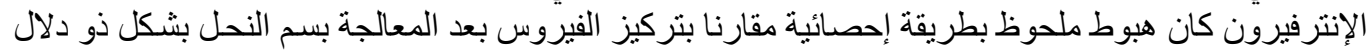

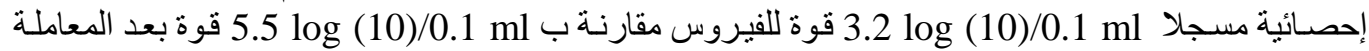

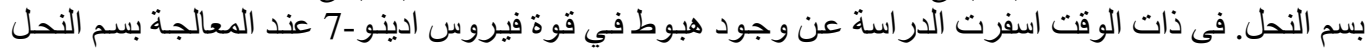

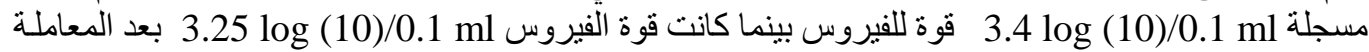

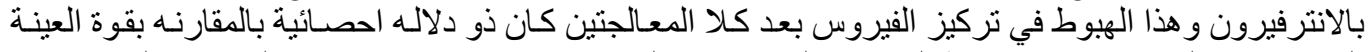

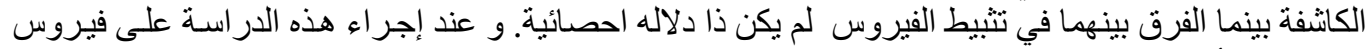

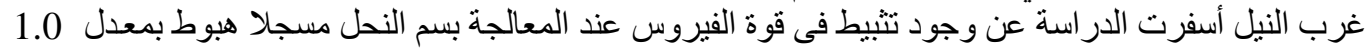

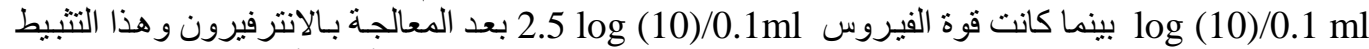

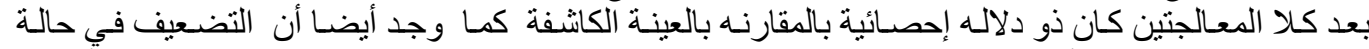

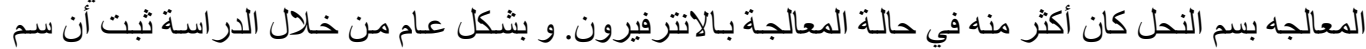

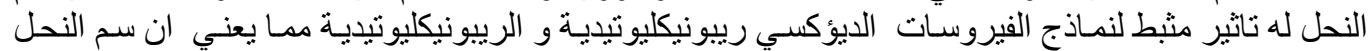
كمضاد للفيروسات في حاجة الي مزيد من الدر استات المستقبلية 